\title{
THE EARNINGS AND EMPLOYMENT OF COMMUNITY COLLEGES' GRADUATES: OCCUPATIONAL FIELD AND GENDER ANALYSIS
}

\author{
Z Buang ${ }^{1}$, M M Mohamad ${ }^{2}$, A Ahmad $^{3}$, and N Yuniarti ${ }^{4}$ \\ ${ }^{1,2}$ Faculty of Technical and Vocational Education, Universiti Tun Hussein Onn Malaysia \\ ${ }^{3}$ School of Education, Faculty of Social Sciences and Humanities, Universiti Teknologi Malaysia \\ ${ }^{4}$ Dept.of Electrical Engineering Education, Universitas Negeri Yogyakarta, Indonesia \\ Email: zurani7474@gmail.com,mimi@uthm.edu.my
}

\begin{abstract}
Community College Malaysia is one of the Technical Education and Vocational Training Institutions in the country that plays an important role in steering the country's aspirations to become a developed nation by 2020. It focuses mainly on the supply of human capital among the youth future worker fit with skills, competencies and efficient industry requirements. However, the income earned varies widely based on the industry's ability to provide employment. The income factors led to an increase or decrease in the number of graduates' employability. There are more than ten categories of programs offered by community colleges and the numbers of employability relating to the demand from industries providing job opportunities to skilled workers. Therefore, this study aims to conduct a descriptive analysis of the earnings and employment of Community Colleges graduates based on occupational field and gender. The data were obtained by the survey of Community Colleges graduates in 2018. The study population consisted of 7725 graduates and 367 respondents were involved as samples who answered their respective job status in graduate's employability survey provided by the ministry. The result shows that most respondents received a salary between RM1501-RM2000, while the rest of the graduates earned between RM1001-RM1500 and RM1001-RM1500. In the gender factor of employment, female graduates exceed compared to male graduates on the income scale of RM1000 and below. However, at higher income levels of RM1501-2000 and above, male graduates earn more than their counterparts, the female graduates. The findings of this study are expected to be a future guide and encouragement, especially for community colleges to study skill programs that are in line with industry requirements and produce a competent and dynamic human capital to enhance the country's economy.
\end{abstract}

Keywords: earnings and employment of community colleges' graduates, gender analysis, occupational field

\section{INTRODUCTION}

One of today's educational challenges is the readiness of the institution to meet the needs of the industry is preparing the graduate to fit with the skill for ready to work [1]. The Malaysian Higher Education Plan 2015-2025 is undergoing major changes in higher education. There are many outstanding educational achievements in this country. However, the industrial revolution is changing the educational landscape of the 21 st century. According to Leach [2], educational goals have also been modified to prepare students for the labor market. Marketability has been a debate in the field of academic research for the past twenty years [3]-[5]. Following this change, the Malaysian Ministry of Education is concerned regarding the issue of qualifications of graduates. The percentage of unemployed youth is higher than that of the uneducated. Shanmugam [6] found that in $2015,15.3 \%$ of 405,000 unemployed youths were educated. To realize Malaysia as a developed, competitive and high-income country by 2020, the government has allocated RM8.8 billion for 545 public institutions to provide $60 \%$ of the 1.5 million new jobs to TVET skilled workers by 2020 [7]. Empirical studies [8] also found that more than $90 \%$ of favor in the field of skills that were in line with industries' requirements. In this regard, the Malaysian government encourages the Technical Education and Vocational Training Institutions (TVET) to offer training programs based on the current need of the industry so that it can guarantee the marketability of graduates. The government has also allocated RM50 million in the 2019 Budget 
to enhance the country's youth competency. Improvements and investments in education in the country aimed at improving the socioeconomic status and the country's development [7]. Expenditure on education is an investment that ultimately people will gain as much as salaries, allowances, bonuses and increase the income of graduates themselves [9]. Subsequently, increasing the income of these individuals will also boost the country's economic growth [10]. The study also found that $53.5 \%$ of 9871 were male students and the rest were female students. This research was executed to review the income earned by graduates of community colleges, which are also one of TVET institutions in the country. The impact of the research findings also can contribute information on individual income and social-economic improvement for future graduates. This study is to realize the transformation of TVETs agenda to be the first choice of education pathway, which is the best route to facing the challenges of youth in this era of globalization.

The Government has recommended that technical education institutions should offer vocational programs as one of the initiatives to generate higher income and economic growth. The government also recommends that TVET institutions should produce graduates as competent, proactive, analytical, creative and innovative human capital in the face of increasingly testing ballistic challenges. Community College is one of the TVET institutions implementing the competencybased curriculum to comply with the industry needs regarding employment. Therefore, this study aims to provide a descriptive analysis of the earning and employment of Community Colleges based on occupational sector and gender analysis.

The research objectives are (1) to determine the dominant income of the graduates of the Community College of Malaysia, Certificate Year 2018, according to the study cluster; (2) to identify the dominant employment sector preferred for hiring
Community Colleges graduates; and (3) to identify graduates' income of the Community College of Malaysia, Certificate Year 2018, concerning gender.

Lifelong learning (LLL) enables individuals to acquire useful skills that increase employability. It requires the learning activities to enhance knowledge, skills and individual competencies or work-related perspectives [11]. The challenge, facing the Malaysian government, is to combat illiteracy among adults. The group could not get the opportunity to pursue a formal education in early life due to colonial factors, poverty, and undeveloped environment. Lifelong educational programs are implemented with full-time and short-term courses. Short-term courses are offered to fulfill the needs of local communities to improve their quality of life; Longworth [12] has listed following reasons for why this LLL program is so important in this decade: (1) Global demographic interests, (2)The influence of television and media on the development of people's ideas and perceptions.

Environmental conservation requirements, (4) New developments in all aspects of science and technology, (5) Explosion of information and knowledge due to internet usage and communication technology, (6) The need for industry and society to remain innovative and flexible in the work environment, and (7) Individualistic attitudes and family and religious divisions in a growing society.

Until now, Bhorat et al. [13] argue the LLL program has become a widely used model in LLL after the concept of common practice in traditional education across schools and universities. He further stated that in the future, LLL including adult student education could be interpreted as "tail that wags the dog" in all fields of education.

The Community College has been operating since 2001, under the Ministry of Education, and is one of the TVETs providing training and skills needed at all levels as well as secondary education opportunities before entering the labor market or pursuing higher 
education. Community College is a TVET that conducts training of formal skills as well as lifelong learning for youth and the local community. This is to address the major dilemma of the developing world when it comes to the problem faced by higher education graduates of being unable to meet the job market [7]. In his paper Mohd Radzi[14] also stated that knowledge, skills and ethical values are important elements of the industry. The market study found that the income of the graduate with bachelor degree started from RM1501 to RM2500 [14]. It is not in line with the guideline for the minimum salary in Malaysia [15]. The guideline stated RM1,704.20 to RM2084.00 and RM2270 respectively for academic certification in the public sector and skills in the corporate sector. Thus, Jan et al. [16] conducted a study to analyze an issue that is often overlooked in the literature namely how academic performance affects new graduates in terms of income distribution and the results showed that academic performance is not deterministic in the same degree of certification and academic performance of a graduate guarantees employment upon graduation.

The TVET eligibility level (highest certificate) is a major contributor to the return on wages, allowances, bonuses and salaries [14]. Reviews [17] also support the findings. Roslan[18] found that differences in income are large between male and female graduates in the employment sector. Nasir et al. [19] showed that the development of students' competencies focuses on elements of knowledge and practical skills, while the elements of "soft skills", professionalism, norm values, and attitudes are not integrated into specific course evaluations. Overall, the findings show that the development of students' competencies focused on knowledge elements and practical skills, while elements of soft skills, professionalism, norm values, and attitudes are not integrated into the course evaluation.
The challenge for TVETs today is that besides producing sufficient and quality human capital it is also a very important agenda in achieving the country's vision and to cope with the employment needs of 1.6 million people in technical and vocational jobs by 2020.TVET education is to provide students with the knowledge and skills required to perform manual tasks [20]. The failure of TVET in the preparation of competent students will affect the job market. In Malaysia, there is still a mismatch between students' knowledge and skills and industry needs [21]. One of the reasons for the discrepancy between supply and labor demand is due to low levels of job readiness among graduates. The TVET curriculum has a lack of industry perspective and a lack of up-to-date industry knowledge, affecting the quality of student skills [22]. Inappropriate labor supply and demand have resulted in relatively high unemployment, especially in the first year after graduation [23]. Entrepreneurship is one of the youngest paradigms in the field of employment and its existence depends largely on other scientific methods and theories. Malaysia is heading towards being an industrialized country by 2020 where the business sector is expected to grow. It is not just a supportive sector but is more about providing the foundation and technology to ensure greater enterprise development success and to produce knowledgeable entrepreneurs and workers to achieve the status of a developed and highincome nation. Through structured education and training, human beings can be trained with the skills and knowledge needed in the industry [24]. This statement was supported by Ritchie \& Lewis [25], who stated that in today's global development and today's globalization era, employers not only focus on technical or hard skills but also on generic or soft skills so that their employees can adapt. 


\section{METHOD}

The study used a quantitative approach survey design with questionnaires as the instrument. Students attended the convocation were required to fill out the questionnaire. The sample consisted of convocation graduates in 2018 from all Community Colleges of Malaysia. The study involved 10 Community College Diploma programs and 49 certificate programs offered in the Malaysian Community. It involved 9871 people from 89 community colleges.

The population consisted of 7725 Malaysian Community College graduates, in 2018, who answered their respective job status. The stratified sampling method was used to determine the sample size of 367 graduates based on the number of minimum samples method suggested by Kerjie \& Morgan [26]. The selection of a study sample should generalize the population, meet the criteria for questioning and provide accurate and valid information [27], [28]. Random sampling is applied to allow individuals to have the same opportunity to choose from. Given that the number of graduates by field has a significant difference between 6 to 923 people, the numbers of graduates were grouped from the program into the study cluster presented in Table 1.

Table 1. List Cluster of Studies in Malaysian Community College

\begin{tabular}{ll}
\hline No & \multicolumn{1}{c}{ Cluster of Studies } \\
\hline 1 & Special skills \\
2 & Join Hospitality \\
3 & Tourism And Hospitality \\
4 & Services \\
5 & Creative Art And Design \\
6 & Civil Engineering \\
7 & Mechanical Manufacturing \\
8 & Electrical \\
9 & Information technology \\
10 & Argo technology \\
11 & Trade and Management \\
\hline
\end{tabular}

\section{RESULTS AND DISCUSSION}

Table 2 indicates that the dominant income earned by graduates of the Community
College of Malaysia in 2018 is from Tourism and Hospitality clusters followed by the Information Technology cluster. About 12.6\% of Tourism and Hospitality graduates, while $7.3 \%$ of Information Technology graduates earn between RM1001 - RM1500. Overall, 49.6\% received a salary on a scale of RM1001RM1500, 33.9\% received a monthly income on a scale below RM1000. The percentage of income below the scale of RM1501-RM2000 is $83.5 \%$ and is alarming as it does not meet the minimum wage scale set out in the BPGP. The income of the Community College graduates who earn the most, according to the BPGP, is from the Electricity cluster of $3.6 \%$. The findings of this study show that the graduates of the dominant Community College Certificate receive income below the initial income level as proposed by the Ministry of Human Resources [29].

The findings of this study align with the findings of Tuan Abdullah \& Hashim [30] and Allen \& Velden[31] who stated that, overall, the level of hospitality job skills among vocational students in Malaysia is at a high level of efficiency and importance (93.2\%). It hopes to improve the socioeconomic status of the country's youth. Unfortunately, the low income of Community College graduates, as opposed to the government's recommendation, poses some issues that need further study on the part of Community College or industry as to why this situation exists.

Table 3 presents the results showing that the dominant sectors of graduates in the private sector are entrepreneurs, governments, and families. These findings indicate that $78.7 \%$ of community college certificate holders work in private companies to meet industry needs and then graduates choose to venture into entrepreneurship. The findings show that community college graduates can meet the job market in the private sector as well as entrepreneurship as the government has suggested. Because of these statistical results, institutions should play a greater role in expanding and promoting in-institution 
activities with students' engagement. Students need to take the opportunity to develop their potential by actively participating in every activity organized. Students' engagement initiatives in institutional activities will develop students' leadership qualities that will stimulate their cognitive development and social communication.

Table 2.Community College Graduate Income According to the 2018 Study Cluster

\begin{tabular}{lccccccccc}
\hline \multirow{1}{*}{ Study Cluster } & \multicolumn{9}{c}{ Income (RM) } \\
\cline { 2 - 7 } & $\begin{array}{c}1000 \text { and } \\
\text { Bellow }\end{array}$ & $1001-$ & 1500 & 2000 & 2500 & 3000 & 4000 & 10,000 & Total \\
\hline Special skills & 0.3 & 0.6 & 0.3 & 0.0 & 0.3 & 0.0 & 0.0 & 1.4 \\
Join Hospitality & 0.0 & 0.8 & 0.6 & 0.0 & 0.3 & 0.0 & 0.0 & 1.7 \\
Tourism And Hospitality & 8.1 & 12.6 & 2.8 & 0.0 & 0.0 & 0.0 & 0.0 & 23.5 \\
Services & 4.5 & 2.8 & 0.3 & 0.0 & 0.0 & 0.0 & 0.3 & 7.8 \\
Creative Art And Design & 5.6 & 5.6 & 0.8 & 0.6 & 0.0 & 0.0 & 0.0 & 12.6 \\
Civil Engineering & 2.5 & 4.8 & 1.1 & 0.0 & 0.3 & 0.0 & 0.0 & 8.7 \\
Mechanical Manufacturing & 5.0 & 5.9 & 1.4 & 0.3 & 0.3 & 0.0 & 0.0 & 12.9 \\
Electricity & 2.8 & 6.2 & 3.6 & 0.8 & 0.0 & 0.3 & 0.0 & 13.7 \\
Information technology & 3.9 & 7.3 & 0.6 & 0.3 & 0.0 & 0.0 & 0.0 & 12.0 \\
Agrotechnology & 0.3 & 1.1 & 0.0 & 0.0 & 0.6 & 0.0 & 0.0 & 2.0 \\
Trade And Management & 0.8 & 2.0 & 0.6 & 0.3 & 0.0 & 0.0 & 0.0 & 3.6 \\
& 33.9 & 49.6 & 12.0 & 3.1 & 2.8 & 1.1 & 0.3 & 100.0 \\
\hline
\end{tabular}

Table 3. Community College Graduate 2018 According to the Sector of Employments

\begin{tabular}{lccccc}
\hline & \multicolumn{4}{c}{ Percentage of Graduates } \\
\cline { 2 - 5 } Cluster Study & Entrepreneurs & Government & Private & Family & Total \\
\hline Special skills & 0.3 & 0.0 & 0.8 & 0.3 & 1.4 \\
Join Hospitality & 0.0 & 0.0 & 1.7 & 0.0 & 1.7 \\
Tourism And Hospitality & 2.0 & 0.8 & 17.9 & 2.8 & 23.5 \\
Services & 1.7 & 0.0 & 6.2 & 0.0 & 7.8 \\
Creative Art And Design & 3.4 & 0.0 & 7.0 & 2.2 & 12.6 \\
Civil Engineering & 0.3 & 0.3 & 7.3 & 0.8 & 8.7 \\
Mechanical Manufacturing & 1.1 & 0.6 & 9.8 & 1.4 & 12.9 \\
Electrical & 1.7 & 0.0 & 11.5 & 0.6 & 13.7 \\
Information technology & 0.3 & 0.6 & 10.4 & 0.8 & 12.0 \\
Argo technology & 0.0 & 0.6 & 1.4 & 0.0 & 2.0 \\
Trade And Management & 0.3 & 0.0 & 2.5 & 0.8 & 3.6 \\
& 11.2 & 3.1 & 78.7 & 9.8 & 100 \\
\hline
\end{tabular}

Malaysian Community College Graduate Monthly Income Scale by Gender Year 2018 is presented in Table 4. According to Table 4, the result indicates that the percentage of female graduates exceeds as compared to male graduates on the income scale of RM1000 and RM1001-RM1500. While in the income scales of RM1001-1500 and above, male graduates earn more than females. The findings study of
Anne et.al [32] argues that the industry is constantly opening up employment opportunities for male and female graduates to explore the employment industry to enhance and validate their skills in line with current market developments. However, Komathi \& Husaina Banu[7] found that there are significant differences between male and female graduates based on their studies. Although recent studies 
have shown that there are income differences between male and female graduates, researchers suggest that female graduates still have the same opportunity to receive equal pay through activities that increase their marketability. Among the activities that can enhance the marketability of graduates are digital marketing, soft skill programs and active participation in hands-on skills in workshops with high confidence.

Table 4. Malaysian Community College Graduate Monthly Income Scale by Gender Year 2018

\begin{tabular}{lcccccccc}
\hline \multirow{3}{*}{ Gender } & \multicolumn{8}{c}{ Percentage of Income (RM) } \\
\cline { 2 - 8 } & $\begin{array}{c}1000 \text { and } \\
\text { bellow }\end{array}$ & $1001-$ & $1501-$ & $2001-$ & $2501-$ & $3001-$ & $5001-$ & Total \\
\hline Male & 14.2 & 24.8 & 2000 & 2500 & 3000 & 4000 & 10,000 & 50.7 \\
Females & 18.8 & 23.4 & 4.6 & 1.6 & 2.2 & 0.5 & 0.3 & 49.3 \\
& 33.0 & 48.2 & 11.7 & 3.0 & 2.7 & 1.1 & 0.3 & 100.0 \\
\hline
\end{tabular}

\section{CONCLUSION}

The findings show that diploma graduates received higher minimum income than the certificate, where the Travel and Hospitality cluster graduates received higher minimum income than the other study clusters in community colleges, followed by Information Technology and Electrical clusters. The findings of this study indicate that community college certified graduates have been able to place themselves in the employment sector especially in the private sector. In line with the national labor market requirements, male graduates earn a higher income in every income scale except for income below RM1000. This can help to improve the socioeconomic status of higherincome families. Hopefully, these research findings will contribute the elements as a supporting guide and encouragement especially for community colleges to study skill programs that are in line with industry requirements and produce a competent and dynamic human capital to enhance the country's economy. It is also hoped that this will be able to hold discussions with industry giving income to graduates as outlined in graduate employability.

\section{REFERENCES}

[1] A. Hasan and P. Pardjono, "The Correlation of Higher Order Thinking Skills and Work Readiness of Vocational High School Students," $J$. Pendidik. Teknol. dan Kejuru., vol. 25, no. 1, pp. 52-61, Apr. 2019, doi: 10.21831/jptk.v25i1.19118.

[2] T. Leach, "The Ideology and Politics of Vocational Education in an Age of Austerity ," Res. Post-Compulsory Educ., vol. 22, no. 2, pp. 221-236, Apr. 2017 , doi: 10.1080/13596748.2017.1314681.

[3] D. Graham, "Embedding Employability Behaviours," J. Work. Manag., vol. 9, no. 1, pp. 35-50, Jun. 2017, doi: 10.1108/jwam-01-2017-0001.

[4] P. Siivonen and U. Isopahkala-Bouret, "Adult Graduates' Negotiations of Age(Ing) and Employability," J. Educ. Work, vol. 29, no. 3, pp. 352-372, Apr. 2016 , doi: 10.1080/13639080.2014.939161.

[5] S. Williams, L. J. Dodd, C. Steele, and R. Randall, "A Systematic Review of Current Understandings of Employability. Journal of Education and Work," J. Educ. Work, vol. 29, no. 8, pp. 877-901, Nov. 2016, doi: 10.1080/13639080.2015.1102210.

[6] M. Shanmugam, "Unemployment among Graduates Needs to be Sorted out Fast," Star, Mar. 25, 2017.

[7] C. Komathi and K. Husaina Banu, "TVET Graduate Income Training," 2019.

[8] W. Watisin, N. I. Ismail, and M. M. H. Hashim, "The Problems of Bilateral Relations between Educational Institutions and Industrial Committee towards Work-Based Learning in Malaysia," Procedia - Soc. Behav. Sci., vol. 172, no. 1, pp. 352-358, 2015.

[9] L. Pamela, "Staying-On after TwentyOne: The Return to Postgraduate Education," Econ. Res. Pap. Ser., 2016.

[10] G. Becker, Human capital: A Theoretical and Empirical Analysis with 
Special Preference to Education. Chicago: University of Chicago Press, 1993.

[11] European Commission, Innovation in a Knowledge-Driven Economy. Luxembourg: European Commission, 2000.

[12] N. Longworth, Lifelong Learning in Action; Transforming Education in the 21st Century. London and New York: Routledge Falmer, 2003.

[13] H. Bhorat, R. Kanbur, and N. Mayet, "Minimum Wage Violation in South Africa. DPRU," Capet. Inf. Syst., vol. 18, no. 5, pp. 195-203, 2010.

[14] N. A. Mohd Radzi, R. Ismail, and B. . Poo, "Rate of Return on Education by Gender in Malaysia," in National Economic Conference of Malaysia to VII (PEREMEM VII), Economic and Social Transformation Towards Developing Countries, Ipoh, Perak, 4 - 6 June 2012, 2012.

[15] M. . Mohd Daud, A. R. . Mohamed, N. Q. Andin Abdullah, and M. S. Nordin, "Penilaian Pembelajaran Berasaskan Kompetensi: Kajian Kes di Kolej Komuniti," in International Seminar on Technical and Vocational Education, 2014, pp. 641-632.

[16] J. J. Soon, A. S. H. Lee, H. E. Lim, I. Idris, and W. Y. K. Eng, "Cubicles or Corner Offices? Effects of Academic Performance on University Graduates' Employment Likelihood and Salary," Stud. High. Educ., pp. 1-16, Mar. 2019, doi: 10.1080/03075079.2019.1590689.

[17] OECD, "Structural Policy Country Notes for Emerging Malaysia," in Economic Outlook for Southeast Asia, China and India 2014: Beyond The Middle-Income Trap, OECD 2013, 2013, p. 16.

[18] N. E. Roslan, "Transformation of Vocational Basic Education Program in Ministry of Education Secondary School Malaysia," Tun Hussein Onn University Malaysia, 2013.

[19] A. N. Md Nasir, A. Ahmad, A. Udin, M. H. Noordin, and D. F. Ali, "Kajian Keperluan Kerangka Pengajaran Praktikal Subjek Elektronik di Kolej Vokasional," in International Seminar On Technical And Vocational Education, 2014.

[20] M. Nylund, P. A. Rosvall, and K. Ledman, "The Vocational-Academic
Divide in Neoliberal Upper Secondary Curricula: The Swedish Case," J. Educ. Policy, vol. 32, no. 6, pp. 788-808, Nov. 2017, doi: 10.1080/02680939.2017.1318455.

[21] Kagimula, "Elemen Ketidaksepadanan (Mismatch) antara Program Diploma Kejuruteraan Mekanikal Dengan Keperluan Industri," Universiti Tun Hussien Onn Malaysia, 2007.

[22] S. Notosusanto, "Elimination of Discrimination against Women," Compass, Aug. 12, 1994.

[23] D. Fleming and H. Sborg, "Malaysian Skills Development and the MiddleIncome Trap," in 16th ILERA 2012 World Congress, 2012, pp. 1-21.

[24] H. Hassan, R. Ahmad, and A. Bahari, "Kemahiran Insaniah dan Kepentingan Penerapannya dalam Program Baktisiswa Perdana," UniMAP, 2008.

[25] J. Ritchie and J. Lewis, Qualitative Research Practice: A Quide for Social Science Students and Researchers. London: SAGE Publications Ltd, 2003.

[26] R. V. Krejcie and D. W. Morgan, "Determining Sample Size for Research Activities," Educ. Psychol. Meas., vol. 30, no. 607-610, 1970.

[27] J. Manson, Qualitative Researching Second Edition. London and New Delhi: Sage Publications, 2002.

[28] G. Psacharopoulos and H. A. Patrinos, "Returns to Investment In Education: A Further Update," Educ. Econ., vol. 12, no. 2, pp. 111-134, Aug. 2004, doi: $10.1080 / 0964529042000239140$.

[29] Ministry of Human Resources, "Buku Panduan Gaji," 2016.

[30] T. A. K. Tuan Abdullah and M. . Hashim, "Pembelajaran Berasaskan Proses Pekerjaan (WPBL) di Kolej Vokasional Malaysia," in International Seminar On Technical And Vocational Education, 2014.

[31] J. Allen and R. Van Der Velden, "Educational Mismatches versus Skill Mismatches: Effects on Wages, Job Satisfaction, and On-The-Job Search," Oxford Econ. Pap., vol. 3, pp. 434-452, 2001.

[32] D. Anne, L. Phil, C. Michael, and H. Tiffany, "The Private Rate of Return to a University Degree in Australia," Aust. J. Educ., vol. 59, no. 1, pp. 97-112, 2016. 